\title{
THE SWEDISH TIME SCALE: A POTENTIAL CALIBRATION TOOL FOR THE RADIOCARBON TIME SCALE DURING THE LATE WEICHSELIAN
}

\author{
BARBARA WOHLFARTH, ${ }^{1}$ SVANTE BJÖRCK ${ }^{2}$ and GÖRAN POSSNERT ${ }^{3}$
}

\begin{abstract}
The Swedish Time Scale (STS) is a ca. 13,300-yr-long varve chronology that has been established for the Swedish east coast from $>1000$ overlapping clay-varve diagrams. We describe the present state of the STS and illustrate the application of this worldwide unique varve chronology for AMS radiocarbon measurements. The results are compared to other ${ }^{14} \mathrm{C}$-dated calendar-year chronologies: dendrochronology, laminated lake sediments and U/Th. Our data set agrees with the oldest part of the dendrochronological calibration curve, and with AMS ${ }^{14} \mathrm{C}$-dated lake lamination data and U/Th on corals down to $c a .12 \mathrm{ka}$ calendar years BP. Further back in time, the AMS-dated part of the STS partly compares well with lake lamination chronologies and shows that the difference between ${ }^{14} \mathrm{C}$ and calendar years decreases rapidly between 12,600 and 12,800 calendar years BP. Such a development seems to contrast with U/Th measurements on corals. We suggest that the cause for the divergence among three supposed calendar-year chronologies lies in the fact that the data points on the marine ${ }^{14} \mathrm{C}$ - $\mathrm{U} /$ Th curve are more widely spaced in time than the tightly grouped set of terrestrial AMS ${ }^{14} \mathrm{C}$ dates, and thus are not able to reflect short-term changes in atmospheric ${ }^{14} \mathrm{C}$. Therefore, we argue that the use of the pre-Holocene part of the calibration program is premature and inadvisable.
\end{abstract}

\section{INTRODUCTION}

A qualitative and quantitative interpretation of climatic and environmental data and a correlation of isotope, bio-and lithostratigraphic records require a calibration of the radiocarbon time scale against a calendar-year chronology. The dendrochronological calibration curve has solved this problem for the last $10 \mathrm{ka} \mathrm{BP}$ or $11,350 \mathrm{cal} \mathrm{BP}$ (Kromer and Becker 1993). Beyond $10 \mathrm{ka} \mathrm{BP},{ }^{230} \mathrm{Th}-{ }^{243} \mathrm{U}$ and ${ }^{14} \mathrm{C}$ measurements on corals provided promising results to extend the calibration curve back to $\mathrm{ca}$. $18 \mathrm{ka}$ $\mathrm{BP}$ (Bard et al. 1993). However, terrestrial records such as accelerator mass spectrometry (AMS) ${ }^{14} \mathrm{C}$ dates from the glacial varves of the Swedish Time Scale (STS) (Björck et al. 1995; Wohlfarth et al. 1993, 1995) and from laminated lake sediments in Germany and Switzerland (Hajdas 1993; Hajdas et al. 1993) showed that, although a good correspondence exists among corals, tree rings and varved sediments as far back as $c a .10 \mathrm{ka} \mathrm{BP}$, varve data and $\mathrm{U} / \mathrm{Th}$ records disagree between $c a .10,500$ and $12,500 \mathrm{BP}$. Here we present new AMS ${ }^{14} \mathrm{C}$ dates from the Late Weichselian part of the STS, a varve chronology spanning the last ca. 13,300 calendar years (Björck et al. 1992; Wohlfarth et al. 1993) and discuss our results in respect to other high-resolution ${ }^{14} \mathrm{C}$-dated calendar-year chronologies: annually laminated lake sediments, dendrochronology and U/Th-dated corals.

\section{Difference Between Glaciolacustrine Varved Clays And Organic Varves}

The term "varve" (from the Swedish word varv = turn, round, layer) was introduced by De Geer (1912) to name a glaciolacustrine sediment with distinct alternating summer (silt) and winter (clay) layers. Although later defined as "a sedimentary bed or lamina or sequence of laminae deposited in a body of still water within one year's time, specifically a thin pair of graded glaciolacustrine layers seasonally deposited (usually by meltwater streams) in a glacial lake or other body of still water in front of a glacier" (Gary et al. 1972), the term "varve" is now generally applied to describe the structure of a sediment regardless of its depositional environment and lithologic composition (Sturm 1979). This means that different types of annually deposited sediments, e.g. glaciolacustrine varved clays and annually laminated lake sediments, are grouped together under the term "varve", although their lithology and depositional environment are completely different. Varved clays are glaciolacustrine sedi-

\footnotetext{
${ }^{1}$ Department of Quaternary Geology, Lund University, Tornavägen 13, S-22363 Lund, Sweden

${ }^{2}$ Geological Institute, Copenhagen University, Øster Voldgade 10, DK-1350 Copenhagen, Denmark

${ }^{3}$ The Svedberg Laboratory, Uppsala University, Box 533, S-75121 Uppsala, Sweden
} 
ments that were deposited in a proglacial lake either in front of the retreating ice margin or by glacial meltwater streams. These sediments are composed of clearly separated, several centimeter-thick, light-colored silty-sandy (summer) and dark-colored clayey (winter) layers. The coarsest particles were deposited first (by bottom transport) as a result of rapid spring and summer ice melt, whereas the finer clay particles remained in suspension and settled during winter, when the lake was frozen. Annually laminated lake sediments or organic varves form in deep lakes with oxygen-deficient basal water and result from seasonal variations in the accumulation of organic detritus (Saarnisto 1986). The laminations may be due to the seasonal abundance of diatoms (Simola 1977), precipitation of $\mathrm{CaCO}_{3}$ (Kelts and Hsü 1978), formation of iron oxides (Anthony 1977, Renberg 1981) or variations in mineral matter (Renberg 1976). The thickness of these laminae may vary between 0.5 and $1 \mathrm{~mm}$.

\section{The Swedish Time Scale}

More than 100 yr ago, the Swedish geologist Gerard De Geer (1884), discovered alternating layers of light-colored silt and dark-colored clay, which reminded him of tree rings. He understood that these layers had been deposited by glacial meltwater in the Baltic basin during the retreat of the Fennoscandian ice sheet and reasoned that by establishing and correlating varve diagrams from south to north it should be possible to reconstruct the timing of the deglaciation of the Fennoscandian inland ice. After extensive varve measurements along the Swedish east coast, De Geer (1912) and Lidén (1913) presented the first deglaciation chronology for Sweden, the STS, which was divided into "gotiglacial", "finiglacial" and "postglacial" sections (De Geer 1912; Lidén 1913). During the following years, varved-clay measurements and correlations were made not only in Sweden (e.g., Lidén 1938; De Geer 1940), but in former glaciolacustrine basins in many other parts of the world (e.g., Sauramo 1923; Antevs 1932; see Zeuner 1950). However, De Geer's (1930) so-called "teleconnections" (between different areas of glaciation and different sedimentary basins) and the uncertainties in many of the old varved-clay connections provoked controversies, which also influenced the international image of the Swedish varve chronology (e.g., Lundqvist 1975, 1985).

In Sweden, however, many geologists understood the potential of De Geer's research and worked during the last $20 \mathrm{yr}$ on a revision, refinement and extension of the Swedish varve chronology, following the principles outlined by Strömberg (1983): 1) all varve diagrams that are part of the STS have to be established on varved clays deposited in the same sedimentary basin, i.e., the Baltic; 2) correlations among varve diagrams are to be made only over short distances; and 3) reliable correlations must follow the retreating ice margin.

The STS (Fig. 1) is now completely revised, which means that all old varve connections have been checked and several hundred new varve diagrams have been added (Strömberg 1985, 1989, 1994; Kristiansson 1986; Ringberg 1991; Brunnberg 1995). The chronology is linked to the present through extensive studies by Cato $(1985,1987)$ in the River Ångermanälven, where varves were formed throughout the Holocene. Further, the local and revised chronologies in southeastern Sweden (Kristiansson 1986; Ringberg 1991) have been connected to the STS (Strömberg 1994; Wohlfarth et al. 1993, 1995; Wohlfarth and Holmquist, ms.). Several independent approaches also enable us to test and confirm the validity of the STS:

1. Cato (1987) confirmed the annual character of the postglacial varves by comparing the mean annual varve thickness to mean annual discharge records. Similar results were obtained by comparing the mean annual thickness of glaciolacustrine varves with mean annual temperatures, precipitation and discharge records (Perkins and Sims 1983; Leonard 1985; Deslodges 1994; Leemann and Niessen 1994). The length of the postglacial part of the STS can also be directly compared with annual lake lamination chronologies (Cato 1992). 


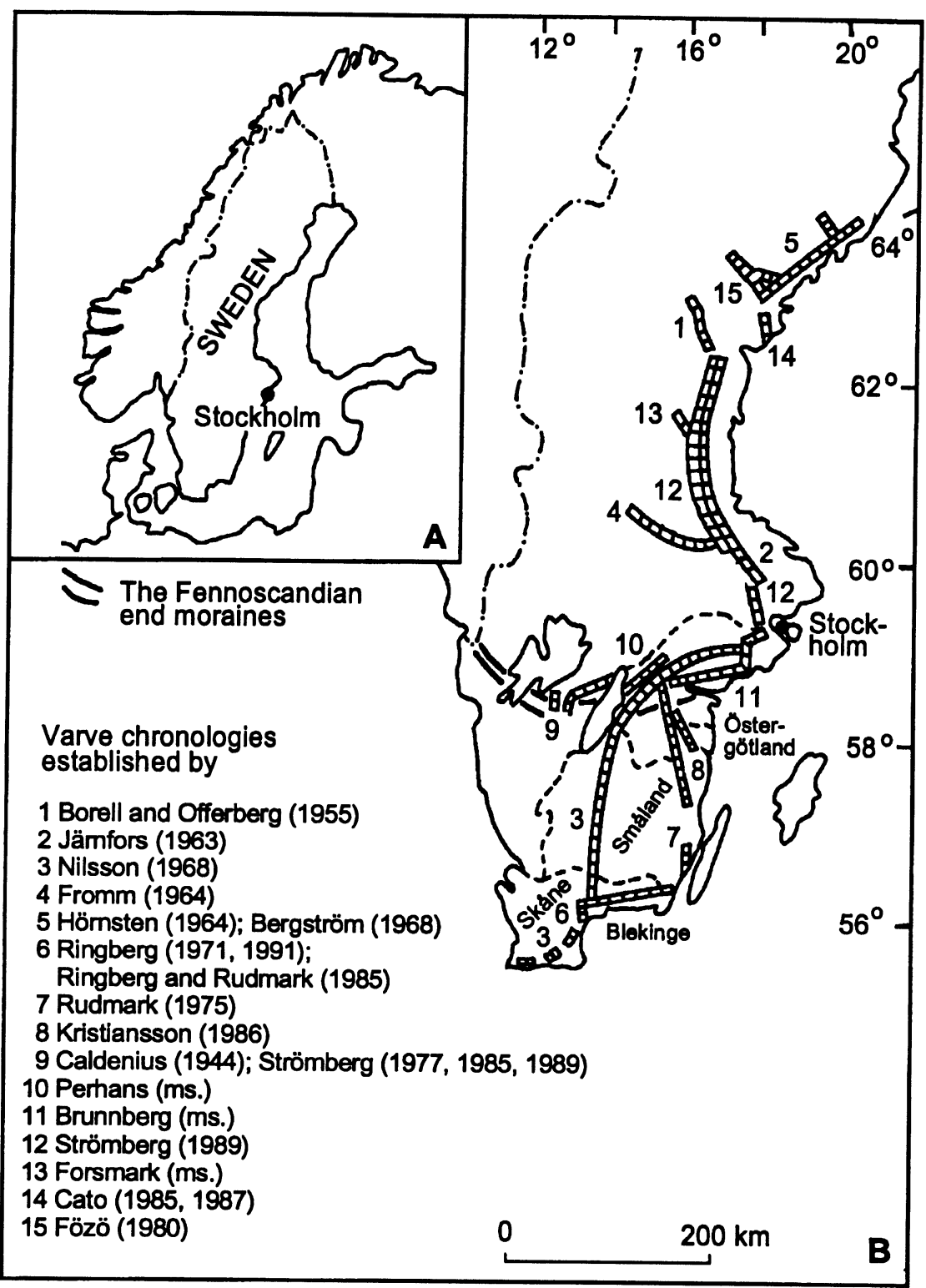

Fig. 1. Sweden (A) and the location of the varved-clay chronologies (B) on which the revised STS is based. Modified after Strömberg (1985); see Strömberg (1985) for references.

2. The first rapid recession of the ice margin in middle Sweden is dated to $c a .10,940$ (estimated uncertainty: $+100 /-250$ ) varve years $\mathrm{BP}$ and the second rapid ice retreat to $c a .10,740$ varve years BP, which corresponds, according to Strömberg (1994), to the Younger Dryas (YD)/ Holocene transition. In southern Sweden, the end of the YD stadial (not pollen zone) is indicated by insect, plant and marine records showing an increase in temperature already at $c a$. $10,200{ }^{14} \mathrm{C}$ BP (bulk dates) (Berglund et al. 1994) or 10,000-9900 ${ }^{14} \mathrm{C}$ BP (AMS dates on terrestrial macrofossils) (Björck et al. $\mathrm{ms}$.). We believe this climatic signal may be synchronous 
with the first rapid retreat of the ice margin at $c a .10,940$ varve years BP, and that this part of the varve chronology belongs to the later part of the YD chronozone.

3. We know that the second Baltic Ice Lake (BIL) drainage, which marks a drastic event in the history of the Baltic Sea, occurred at ca. 10,980 varve years BP (Strömberg 1994). The effect of the drainage can be easily seen in varved-clay sequences (Strömberg 1994), in the sudden isolation of lake basins from the BIL (Björck 1981) and as sandy-silty layers in Late Weichselian lacustrine deposits, where it marks the YD/Preboreal transition zone (Svensson 1989; Björck 1995).

4. The pollen zones established in the Late Weichselian part of the varve chronology confirm, in comparison with pollen-analyzed lake sediments, the length of the chronology (Fig. 2). We know that the varves $c a .12,700$ varve years BP can be assigned to the Bølling pollen zone and that the varves between $c a .12,560$ and 12,700 varve years BP were deposited during the Older Dryas pollen zone (Björck 1981; Björck and Möller 1987, Wohlfarth et al. 1994).

5. Statistical analyses on the Late Weichselian part of the clay-varve connections show high statistical coefficients and confirm the original varve correlations (Wohlfarth and Holmquist, ms.). As an example, Figure 2 displays the number of diagrams and their overlap on which the Late Weichselian part of the STS is built. These sites are $<10 \mathrm{~km}$ apart and the overlap per year is based on 5-30 sites per year. This closely grouped set of sites, together with ice recession rate calculations, make it unlikely that many varves are missing from the Late Weichselian part of the STS. If we added $c a .2000$ varves to the oldest $c a .1200-1500$ varves, this would mean that perhaps 3500 varves were deposited during the Bølling/Allerød pollen zones in southern Sweden (Figs. 2,3). As a consequence, the ice recession of 75-150 m/yr (Kristiansson 1986) during these warm periods would not only decrease by $60 \%$ and equal the recession rate during the YD cold phase (30-40 m yr-1), but also be incomparable to a retreat of ca. $100-200 \mathrm{~m} \mathrm{yr}^{-1}$ during the early Preboreal (Strömberg 1994) or to a retreat of $200-300 \mathrm{~m} \mathrm{yr}^{-1}$ during the early Holocene (Strömberg 1985).

The revised STS represents a ca. 13.3 ka long varve chronology, established from the dense overlap and connection of $>1000$ varve diagrams from localities along the Swedish east coast. It constitutes a firm, well-established and consistently checked, independent chronology.

\section{METHODS}

To test the feasibility of the STS as a Late Weichselian calibration tool for ${ }^{14} \mathrm{C}$, we cored present-day lake and peat bog sites, which were part of the BIL, where varved clays deposited during the deglaciation, and we expected accumulation of terrestrial macrofossils (Wohlfarth et al. 1993, 1994). For each site, we created a clay-varve diagram and correlated it (visually and statistically) to the established varve diagrams of the STS from neighboring sites. Varved-clay samples comprising ca. 20100 varve-year segments were then sieved through a $0.5-\mathrm{mm}$ mesh. Dispersicn of the clay particles was facilitated by storing the samples overnight in distilled water, to which we added a few drops of $5 \% \mathrm{Na}_{4} \mathrm{P}_{2} \mathrm{O}_{7}$. Visible macrofossils were picked out during sieving, determined and submitted for AMS measurements. Only leaves of Late Glacial terrestrial macrofossils, such as Betula nana, Dryas octopetala, Salix herbacea, Salix polaris and Salix reticulata were used for dating (Table 1). However, our first samples included brown mosses and insect fragments. Previously, we stored our macrofossil samples in distilled water, to which we added several drops of $2 \% \mathrm{HCl}$ to attain a $\mathrm{pH}$ of ca. 2 and kept them in a cold room for 1 month to $1 \mathrm{yr}$ before the AMS measurements were made. After we realized that bacteria and fungi can easily attack wet-stored samples, we then submitted all samples immediately following sieving and identification to the ${ }^{14} \mathrm{C}$ laboratory. We subjected the 


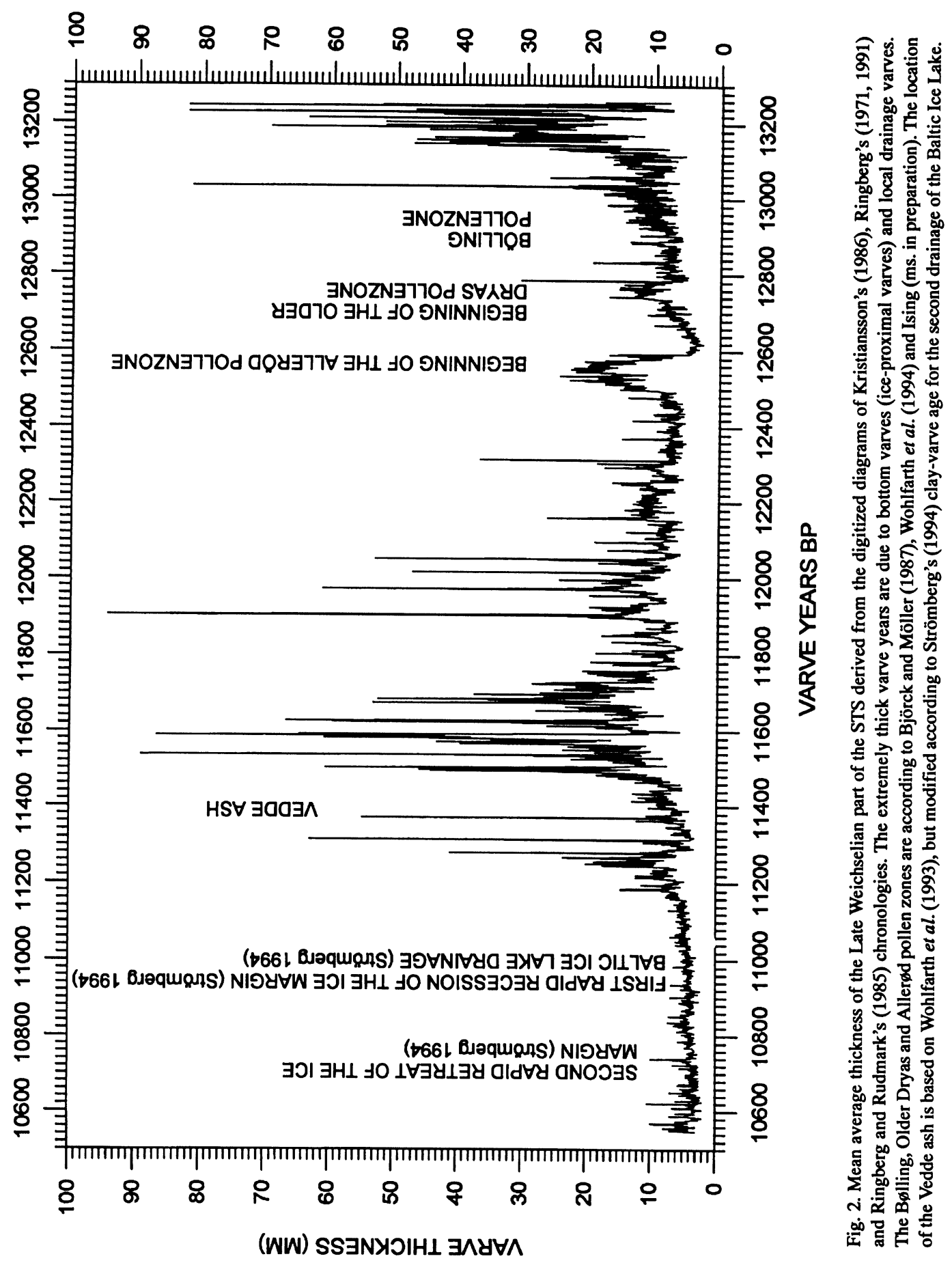




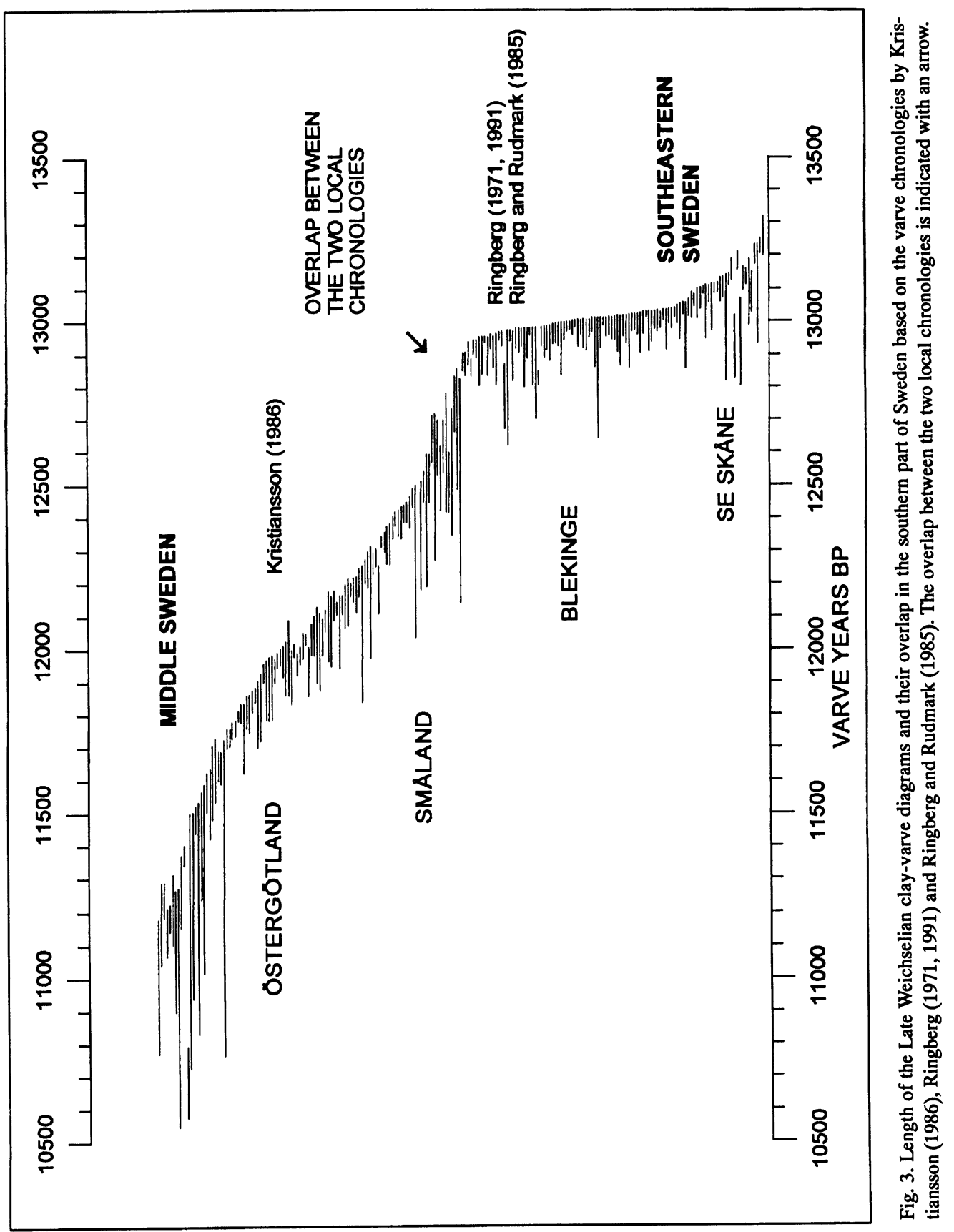


samples to acid-alkali-acid (AAA) chemical pretreatment $\left(1 \% \mathrm{HCl}\right.$ and $0.5 \% \mathrm{NaOH}$ at $80^{\circ} \mathrm{C}$ for 4 h) followed by combustion with CuO, Fe-catalytic graphitization (Vogel et al. 1984) and AMS measurements with the Uppsala EN-tandem accelerator (Possnert 1990).

TABLE 1: AMS-Dated Macrofossils and Age of the Samples According to the Swedish Time Scale

\begin{tabular}{|c|c|c|c|c|}
\hline $\begin{array}{l}\text { Labno. } \\
\text { (Ua-) }\end{array}$ & Location & Sample* & $\begin{array}{l}\text { Swedish Time } \\
\text { Scale } \\
\text { (varve yr BP) }\end{array}$ & $\begin{array}{l}{ }^{14} \text { C AMS age } \\
\text { (yr BP) }\end{array}$ \\
\hline 2469 & Farslycke & $\begin{array}{l}\text { Salix indet. (L, ff), Salix (L), Salix cf. herbacea } \\
\text { (L), Betula nana (L), wood (ff) }\end{array}$ & $12,748 \pm 42$ & $12,740 \pm 150$ \\
\hline 2741 & Mullsjön & Dryas octopetala (L, ff) & $11,033 \pm 54$ & $9,640 \pm 190$ \\
\hline 2742 & Mullsjön & Betula/Salix (L, ff), brown mosses (L, F, stems) & $11,361 \pm 26$ & $9,945 \pm 115$ \\
\hline 2747 & Skirgöl & $\begin{array}{l}\text { Dryas octopetala (L), Betula/Salix (L), insects, } \\
\text { ?Oligocheta cocc. }\end{array}$ & $\begin{array}{l}\text { 2nd drainage of } \\
\text { the BIL } \dagger\end{array}$ & $10,345 \pm 150$ \\
\hline 2748 & Skirgöl & $\begin{array}{l}\text { Dryas octopetala }(\mathrm{L}, \mathrm{ff}), \text { Salix/Betula }(\mathrm{L}, \mathrm{ff}) \text {, } \\
\text { brown moss }(\mathrm{L}) \text {, insects, ?Oligocheta cocc. }\end{array}$ & $\begin{array}{l}\text { 2nd drainage of } \\
\text { the BIL } \dagger\end{array}$ & $10,540 \pm 140$ \\
\hline 2749 & Skirgöl & $\begin{array}{l}\text { Betula nana }(\mathrm{F}), \text { Salix/Betula }(\mathrm{L}, \mathrm{ff}) \text {, insects, } \\
\text { ?Oligocheta cocc. }\end{array}$ & $\begin{array}{l}\text { 2nd drainage of } \\
\text { the BIL } \dagger\end{array}$ & $10,965 \pm 100$ \\
\hline 2750 & Toregöl & $\begin{array}{l}\text { Dryas octopetala (L, ff), Betula/Salix (L, ff), } \\
\text { insects, UP }\end{array}$ & $12,571 \pm 20$ & $11,520 \pm 225$ \\
\hline 2752 & Toregöl & $\begin{array}{l}\text { Dryas octopetala(L, ff), Betula/Salix (L, ff), } \\
\text { insects, UP }\end{array}$ & $12,571 \pm 20$ & $11,820 \pm 150$ \\
\hline 2753 & Hargsjön & Betula/Salix (L, ff), UP & $12,045 \pm 44$ & $10,480 \pm 150$ \\
\hline 3131 & Tynn & Salix indet. (L, ff, B), Dryas octopetala (L, F) & $12,092 \pm 32 \ddagger$ & $10,890 \pm 120$ \\
\hline 3132 & Dönhyltagyl & Dryas octopetala (F, L ff), Salix polaris (L) & $12,649 \pm 16$ & $12,090 \pm 185$ \\
\hline 4212 & Mullsjön & Salix herbacea (Lf), Salix undiff. (Lf) & $\begin{array}{l}\text { 2nd drainage of } \\
\text { the BIL } \dagger\end{array}$ & $10,160 \pm 115$ \\
\hline 4214 & Mullsjön & $\begin{array}{l}\text { Salix undiff. (Lf; 1B), Salix/Betula (L), Betula } \\
\text { nana (Lf) }\end{array}$ & $11,121 \pm 11$ & $10,170 \pm 195$ \\
\hline 4215 & Mullsjön & $\begin{array}{l}\text { Salix undiff. (Lf), Salix herbacea (Lf), Betula } \\
\text { nana(Lf), Salix/Betula (Lf),Oxyria (S), Caryopy- } \\
\text { llacea (S) }\end{array}$ & $11,181 \pm 48$ & $10,140 \pm 155$ \\
\hline 4216 & Mullsjön & Salix sp. (Lf), Betula nana (Lf), Oxyria (S) & $11,309 \pm 20 \ddagger$ & $10,620 \pm 155$ \\
\hline 4217 & Mullsjön & Salix herbacea (Lf) & $11,344 \pm 14 \ddagger$ & $10,330 \pm 175$ \\
\hline 4245 & Skälgylet & Salix polaris (L), Salix/Betula (Lf) & $12,758 \pm 7$ & $12,330 \pm 370$ \\
\hline 4246 & Skälgylet & Salix polaris (Lf), Salix/Betula (Lf) & $12,733 \pm 17$ & $12,590 \pm 130$ \\
\hline 4247 & Farslycke & Salix/Betula (Lf) & $12,793 \pm 31$ & $12,595 \pm 360$ \\
\hline 4248 & Farslycke & Salix polaris (Lf), Salix/Betula (Lf) & $12,739 \pm 22$ & $12,310 \pm 145$ \\
\hline
\end{tabular}

${ }^{*} \mathrm{~L}=$ leaves; $\mathrm{ff}$ = fragments; $\mathrm{B}$ = budscales; $\mathrm{F}$ = fruits; $\mathrm{S}$ = seeds; UP = unspecified Late Glacial macrofossils $\nmid B I L=$ Baltic Ice Lake. The drainage of the BIL is dated at 10,980 varve years BP (Strömberg 1994). See text for further explanations.

$¥$ The connection of Ua-4216, Ua-4217 and Ua-3131 is preliminary.

\section{RESULTS}

As shown in Table 1, we obtained 16 dates on macrofossils from varved clays, 3 dates (Ua-2747, $-2748,-2749)$ on macrofossils from BIL drainage sediments and 1 date (Ua-4212) on macrofossils extracted from the BIL drainage sand, which directly overlies the varved-clay sequence at the Mullsjön site. Our dates for the drainage event range between 10,160 \pm 115 and 10,965 $\pm 100 \mathrm{BP}$, compared to bulk sediment dates of $c a .10,300$ BP obtained on limnic sediments (Svensson 1989; Wohlfarth et al. 1993). Although the great variation between the four dates reflects erosion and redeposition of macrofossils with different age backgrounds, we can conclude that the BIL drainage can 
be dated at a maximum age of $10,160 \pm 115 \mathrm{BP}$, which corresponds to 10,980 varve years $\mathrm{BP}$ (Strömberg 1994). The other measurements (Table 1 ) on macrofossils from varved clays are: 10,980-11,387 BP (Mullsjön); 11,929-12,592 BP (Hargsjön, Tynn, Toregöl); and 12,633-12,824 BP (Dönhyltagyl, Farslycke, Skälgylet). Based on pollen-analytical investigations of the varved clays (Björck 1981; Björck and Möller 1987; Wohlfarth et al. 1994) (see Fig. 2), we know that the oldest ages $(12,740 \pm$ 150 to $12,310 \pm 145 \mathrm{BP}$ ) date approximately the end of the Bølling pollen zone, and that the next younger dates, $11,520 \pm 225$ to $11,820 \pm 150 \mathrm{BP}$, relate to the beginning of the Allerød pollen zone.

\section{Comparison with Other ${ }^{14} \mathrm{C}$-Dated Late Weichselian Calendar-Year Chronologies}

The group of available ${ }^{14} \mathrm{C}$-dated, Late Weichselian calendar-year chronologies comprises the varved clays of the STS, lake lamination/organic varve data, dendrochronology and U/Th-dated corals. Among these different methods, dendrochronology is the best established calendar-year chronology and the resulting dendrochronological calibration curve now extends back to $11,600 \mathrm{cal} \mathrm{BP}$ (Kromer and Becker 1993; Kromer et al. 1994). A floating Late Weichselian dendrochronology from Switzerland has recently been published (Kaiser 1993). This data set is composed of four separate chronologies, a 286-yr Bølling, a 669-yr Allerød-1, a 375-yr Allerød-2 and a 318-yr Allerød3 chronology, linked together by ${ }^{14} \mathrm{C}$ measurements (Kaiser 1993, Fig. 92). This tentative link corresponds to an approximate duration of 1490 calendar years for the Bølling/Allerød interstadial. Although the data set contains invaluable information, the published match between the four floating chronologies is misleading, because it is based on the assumption of a constant production rate of ${ }^{14} \mathrm{C}$, which does not correspond to reality (Kaiser 1993).

Both dendrochronology (Kromer and Becker 1993) and the STS build on hundreds of overlapping data sets, whereas lake lamination chronologies are established on cores from a single lake basin; unlaminated sequences are frequent and varve thickness cannot be compared to other organic varve chronologies. AMS ${ }^{14} \mathrm{C}$-dated lake lamination chronologies are now available from several lakes in Norway (Kråkenäs: Gulliksen et al. 1994), Germany (Holzmaar: Zolitschka et al. 1992, Hajdas 1993), Switzerland (Soppensee: Lotter et al. 1992; Hajdas 1993; Hajdas et al. 1993) Poland (Gosciaz: Goslar et al. 1992; Rozanski et al. 1992; Ralska-Jasiewiczowa et al. 1992; Goslar et al. 1993) and Japan (Suigetsu: Kitagawa et al. 1995). All lake laminations are similar in that they are floating chronologies and several segments in the cores are unlaminated (e.g., Zolitschka et al. 1992; Goslar et al. 1992; Hajdas 1993). This means that they have to be matched to the dendrochronological calibration curve by wiggle matching (e.g., Hajdas 1993; Hajdas et al. 1993) and that the number of varves in the unlaminated sequences has to be estimated (e.g., Hajdas 1993; Goslar et al. 1992). Although paleoecological studies have been made at some of these sites (e.g., Goscíaż: Ralska-Jasiewiczowa et al. 1992), a substantial number of AMS ${ }^{14} \mathrm{C}$ dates has been published only from Holzmaar and Soppensee (Hajdas 1993; Hajdas et al. 1993; Hajdas et al. 1995).

Correlations among our data set and these lake lamination chronologies can be based on a correlation of pollen-zone boundaries or on a comparison of ${ }^{14} \mathrm{C}$ and calendar years. We know, however, that pollen zones are time transgressive because plant communities or individual species may react to a climatic signal with different time lags (Birks and Gordan 1985) and that the bulk ${ }^{14} \mathrm{C}$ dates of the traditional Late Weichselian pollen zone boundaries suffer from a reservoir effect (Olsson 1986; Wohlfarth et al. 1993). Consequently, AMS ${ }^{14} \mathrm{C}$ dates for the same boundary give ages several hundred years younger than a bulk date (Wohlfarth et al. 1993). Because of these uncertainties, we compare in Figure 4 our data set only to lake-lamination chronologies from which a large number of AMS ${ }^{14} \mathrm{C}$ dates are available. 


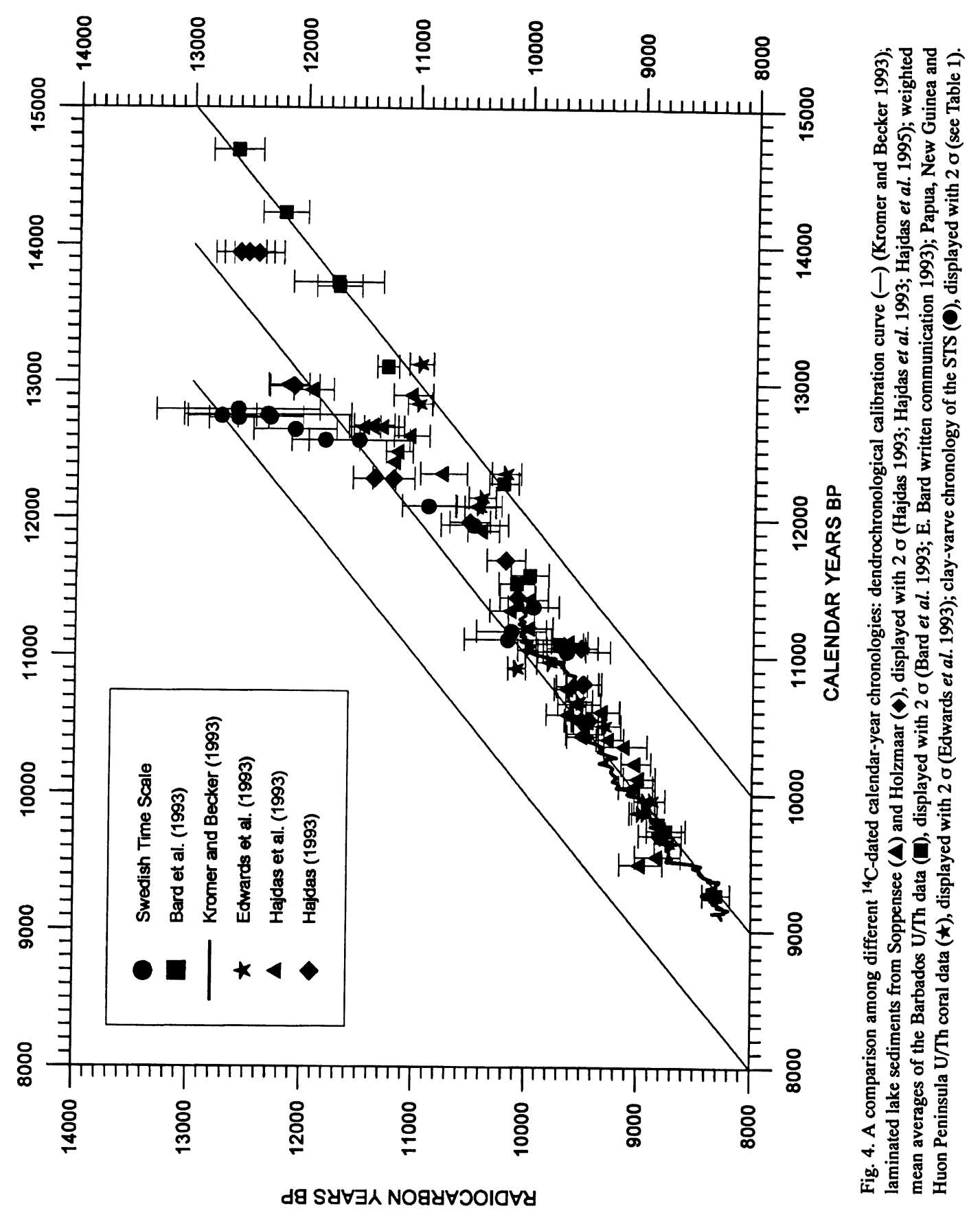


Taking into account a 1-o-uncertainty margin, our five youngest dates relate well with the oldest part of the dendrochronological calibration curve (Kromer and Becker 1993), with ${ }^{14} \mathrm{C}$-U/Th measurements on corals (Edwards et al. 1993; Bard et al. 1993) and with the ${ }^{14} \mathrm{C}$-dated lake lamination records from Soppensee and Holzmaar (Hajdas et al. 1993; Hajdas 1993; Hajdas et al. 1995).

Farther back in time, our ${ }^{14} \mathrm{C} /$ varve dates can be compared only to U/Th (Edwards et al. 1993; Bard et al. 1993) and lake laminations (Hajdas et al. 1993; Hajdas 1993; Hajdas et al. 1995). As shown in Figure 4, all data sets agree within a 1- $\sigma$-uncertainty margin, down to ca. 12,000 calendar years, but start to diverge at $c a .12,300$ calendar years BP. Although ${ }^{14} \mathrm{C}$-U/Th ages show a constant difference of $2 \mathrm{ka}$ to the ${ }^{14} \mathrm{C}$ scale, the ${ }^{14} \mathrm{C} / \mathrm{varve}$ and lake lamination records indicate that the two time scales converge rapidly $\mathrm{ca}$. $12,600-12,800$ calendar years BP. Exceptions are the ${ }^{14} \mathrm{C} /$ lake lamination dates from Holzmaar (Hajdas 1993; Hajdas et al. 1995), which show larger differences between ${ }^{14} \mathrm{C}$ and calendar years with increased age. Such discrepancies between supposed calendar-year chronologies, STS, lake laminations and U/Th data evoke several questions:

1. Are any of these time scales a calendar-year chronology? We rely on the STS as a well-established calendar-year chronology, and we can exclude any large number of missing varves both in the Holocene and in the Late Weichselian part of the time scale (see above). Soppensee and Holzmaar records represent annual chronologies (Lotter et al. 1992; Zolitschka et al. 1992), which can be matched to the dendrochronology-based calibration curve and are independently confirmed by tephra layers (Hajdas 1993; Hajdas et al. 1993; Hajdas et al. 1995). Growth-band measurements on corals have also demonstrated that $\mathrm{U} / \mathrm{Th}$ can be regarded as a calendar-year chronology (Bard et al. 1993).

2. Why do the terrestrial data sets (lake-sediment laminations, STS) show partly similar trends between 12,600 and 12,800 calendar years, but disagree with the ${ }^{14} \mathrm{C}-\mathrm{U} / \mathrm{Th}$ record? The net of ${ }^{14} \mathrm{C}$ dates between 11,700 and 13,100 calendar years BP obtained from both terrestrial chronologies (STS and lake laminations) is much more closely spaced than the dates on the U/Th curve. Between e.g., 12,300 and 13,100 calendar years BP, no values are available on the U/Th curve, whereas $>10$ data points exist for the terrestrial records. This means that changes in atmospheric ${ }^{14} \mathrm{C}$ content can be detected more easily by the $\mathrm{AMS}{ }^{14} \mathrm{C}$ dates from terrestrial chronologies than by the widely spaced ${ }^{14} \mathrm{C}-\mathrm{U} / \mathrm{Th}$ measurements. This would mean that the trend observed in the terrestrial data set is real and would rather represent changes in atmospheric ${ }^{14} \mathrm{C}$ than erroneous varve measurements. The Holzmaar dates (Fig. 4), AMS ${ }^{14} \mathrm{C}$ dates and ${ }^{14} \mathrm{C}$ values (Zbinden et al. 1989) support such an argument.

\section{ConClusion}

The Swedish varve chronology or STS, a ca. 13,300 -yr-long varve chronology, is based on the extensive matching of $>1000$ clay-varve diagrams. By extracting and $\mathrm{AMS}{ }^{14} \mathrm{C}$ dating terrestrial macrofossils from the Late Weichselian varved clays of the STS, we were able to attribute a calendar-year age to each AMS ${ }^{14} \mathrm{C}$ date. Our results agree well with other ${ }^{14} \mathrm{C}$ dated calendar-year chronologies between 11,000 and 12,000 calendar years BP. Farther back in time, our data show a similar trend as ${ }^{14} \mathrm{C}$-dated lake lamination chronologies, but diverge from the AMS ${ }^{14} \mathrm{C}$-U/Th dated corals. However, all these chronologies must be regarded as annual, calendar-year chronologies, so that the cause of this divergence is to be found in the methodological approach. We propose that one reason for the obvious difference between varve and U/Th data lies in the fact that the AMS ${ }^{14} \mathrm{C}$ dates are much closer spaced in time in the terrestrial chronologies than in the U/Th-coral record. Therefore, we argue that a pre-Holocene calibration curve (Stuiver and Reimer 1993) is not yet established. 


\section{ACKNOWLEDGMENTS}

We thank Geoffrey Lemdahl and Gina Hannon for their help in identifying the macrofossils; Lena Barnekow, Leif Björkman, Jonas Ising, Per Lagerås, Hans Lindersson, Siv Olsson and Per Sandgren for their help in the field; Nils-Olof Svensson for his help with the computer program; Lars Brunnberg and Bo Strömberg for many stimulating discussions. This work was made possible through financial support from the Swiss National Science Foundation (SNF), the Swedish Geological Survey (SGU), Swedish Natural Science Research Council (NFR) and the Kungliga Fysiografiska Sällskapet in Lund.

\section{REFERENCES}

Antevs, E. 1932 Korrelation av Europas och Nordamerikas senglaciala skeden. Geologiska Föreningens $i$ Stockholm Förhandlingar 54(2): 191-211.

Anthony, R. S. 1977 Iron-rich rhytmically laminated sediments in Lake of the Clouds, northeastern Minnesota. Limnology and Oceanography and Oceanography 22: 45-54.

Bard, E., Arnold, M., Fairbanks, R. G. and Hameın, B. $1993{ }^{230} \mathrm{Th}-{ }^{234} \mathrm{U}$ and ${ }^{14} \mathrm{C}$ ages obtained by mass spectrometry on corals. In Stuiver, M., Long, A. and Kra, R. S., eds., Calibration 1993. Radiocarbon 35(1): 191-199.

Berglund, B. E., Bergsten, H., Björck, S., Kolstrup, E., Lemdahl, G. and Norberg, K. 1994 Late Weichselian environmental change in southern Sweden and Denmark. Journal of Quaternary Science 9(2): 127-132.

Birks, H. J. B. and Gordon, A. D. 1985 Numerical Methods in Quaternary Pollen Analysis. Academic Press, London: 317 p.

Björck, S. 1981 A stratigraphic study of Late Weichselian deglaciation, shore displacement and vegetation history in south-eastern Sweden. Fossils and Strata 14: 1-93.

1984 Bio- and chronostratigraphic significance of the Older Dryas chronozone-on the basis of new radiocarbon dates. Geologiska Föreningens $i$ Stockholm Förhandlingar 106: 81-91.

1995 A review of the history of the Baltic Sea 13.0 to 8.0 ka BP. Quaternary International 27: 19-40.

Björck, S. and Möller, P. 1987 Late Weichselian environmental history in southeastern Sweden during the deglaciation of the Scandinavian ice sheet. Quaternary Research 28: 1-37.

Björck, S., Cato, I., Brunnberg, L. and Strömberg, B. 1992 The clay-varve based Swedish Time Scale and its relation to the Late Weichselian radiocarbon chronology. In Bard, E. and Broecker, W. S. eds., The Last Deglaciation: Absolute and Radiocarbon Chronologies. NATO ASI Series I, Vol. 2. Berlin, Springer-Verlag: 25-44.

Björck, S., Wohlfarth, B. and Possnert, G. $1995{ }^{14}$ C AMS measurements from the Late Weichselian part of the Swedish Time Scale. Quaternary International 27: 11-18.
Brunnberg, L. 1995 Clay-varve chronology and deglaciation during the Younger Dryas and Preboreal in the easternmost part of the Middle Swedish Ice Marginal Zone. University of Stockholm, Department of Quaternary Research, Quaternaria Series A: Theses and Research Papers 2: 94 p.

Cato, I. 1985 The definitive connection of the Swedish geochronological time scale with the present, and the new date of the zero year in Döviken, northern Sweden. Boreas 14: 117-122.

1987 On the definitive connection of the Swedish Time Scale with the present. Sveriges Geologiska Undersökning, $\mathrm{Ca}$ 68: 55 p.

1992 Shore displacement data based on lake isolations confirm the postglacial part of the Swedish Geochronological Time Scale. Sveriges Geologiska Undersökning, $\mathrm{Ca}$ 81: 75-80.

De Geer, G. 1884 Om den Skandinaviska landsisens andra utbredning. Geologiska Föreningens $i$ Stockholm Förhandlingar 7: 436-466.

1912 A geochronology of the last 12,000 years. 11 Congrès de Géologie International, Comptes Rendues: 241-253.

1930 The Finiglacial sub-epoch in Sweden, Finland and the New World. Geografiska Annaler Stockholm 2: 101-111.

1940 Geochronologia Suecica, Principles. Kungliga Svenska Vetenskapsakademiens Handlingar 18(6): $367 \mathrm{p}$.

Deslodges, J. R. 1994 Varve deposition and the sediment yield record at three small lakes of the southern Canadian Cordillera. Arctic and Alpine Research 26(2): 130-140.

Edwards, R. L., Beck, J. W., Burr, G. S., Donahue, D. J., Chappell, J. M. A., Bloom, A. L., Druffel, E. R. M. and Taylor, F. W. 1993 A large drop in atmospheric ${ }^{14} \mathrm{C}$ / ${ }^{12} \mathrm{C}$ and reduced melting in the Younger Dryas, documented with ${ }^{230} \mathrm{Th}$ ages of corals. Science 260: 962967.

Gary, M., McAfee, R. and Wolf, C. L. 1972 Glossary of Geology. Washington DC, American Geological Institute: 823 p.

Goslar, T. Kuc, T., Pazdur, M. F., Ralska-Jasiewiczowa, M., Rózanski, K., Szeroczynska, K., Walanus, A., 
Wicik, B., Wieckowski, Arnold, M. and Bard, E. 1992 Possibilities for reconstructing radiocarbon level changes during the late Glacial by using a laminated sequence of Goścíaź Lake. In Long, A. and Kra, R. S., eds., Proceedings of the 14 th International ${ }^{14} \mathrm{C}$ Conference. Radiocarbon 34(3): 826-832.

Goslar, T., Kuc, T., Ralska-Jasiewiczowa, M., Rożański, K., Arnold, M. Bard, E., van Geel, B., Pazdur, M. F., Szerozyńska, K., Wicik, B., Więckowski, K., Wala nus, A. 1993 High-resolution lacustrine record of the Late Glacial/Holocene transition in Central Europe. Quaternary Science Reviews 12.

Gulliksen, S., Possnert, G., Mangerud, J. and Birks, H. 1994 AMS ${ }^{14} \mathrm{C}$ dating of the Kråkenäs Late Weichselian sediments. (Abstract) 15 th International ${ }^{14} \mathrm{C}$ Conference, Glasgow, Scotland, 15-19 August.

Hajdas, I. 1993 Extension of the Radiocarbon Calibration Curve by AMS Dating of Laminated Sediments of Lake Soppensee and Lake Holzmaar. Ph.D. dissertation, ETH Zürich No. 10157: 147 p.

Hajdas, I., Ivy, S. D., Beer, J., Bonani, G., Imboden, D., Lotter, A. F., Sturm, M. and Suter, M. 1993 AMS radiocarbon dating and varve chronology of Lake Soppensee: 6000 to $12,000{ }^{14} \mathrm{C}$ years BP. Climate Dynamics 9: 107-116.

Hajdas, I., Zolitschka, B., Ivy-Ochs, S., Beer, J., Bonani, G., Leroy, S. A. G., Negendank, J. Ramrath, M. and Suter, M. 1995 AMS radiocarbon dating of annually laminated sediments from Lake Holzmaar, Germany. Quaternary Science Reviews 14: 137-143.

Holmquist, B. and Wohlfarth, B. (ms.) Statistical evaluation of the Late Weichselian part of the Swedish varve chronology. In preparation.

Kaiser, K. F. 1993 Beiträge zur Klimageschichte vom späten Hochglazial bis ins frühe Holozän rekonstruiert mit Jahrringen und Molluskenschalen aus verschiedenen Vereisungsgebieten. Winterthur, Ziegler Druck- und Verlags-AG: 203 p.

Kelts, K. and Hsü, K. J. 1978 Freshwater carbonate sedimentation. In Lerman, A., ed., Lakes: Geology, Chemistry, Physics. Springer-Verlag: 295-323.

Kristiansson, J. 1986 The ice recession in the southeastern part of Sweden: A varve-chronological time scale for the latest part of the Late Weichselian. University of Stockholm, Department of Quaternary Research, Report 7: 1-132.

Kromer, B. and Becker, B. 1993 German oak and pine ${ }^{14} \mathrm{C}$ calibration, 7200-9439 BC. In Stuiver, M., Long, A. and Kra, R. S., eds., Calibration 1993. Radiocarbon 35(1): 125-135.

Kromer, B., Becker, B., Spurk, M. and Trimborn, P. 1994 Radiocarbon time scale in the early Holocene and isotope time series based on tree-ring chronologies. Terra Nostra 1: 31-33.

Kitagawa, H., Fukuzawa, H., Nakamura, T., Okamura, M., Takemura, K., Hayashida, A. and Yasuda, Y. 1995 AMS ${ }^{14} \mathrm{C}$ dating of the varved sediments from Lake
Suigetsu, Central Japan and atmospheric ${ }^{14} \mathrm{C}$ change during the late Pleistocene. Radiocarbon, this issue.

Leemann, A. and Niessen, F. 1994 Varve formation and the climatic record in an Alpine proglacial lake: Calibrating annually laminated sediments against hydrological and meteorological data. The Holocene 4(1): 1-8.

Leonard, E. M. 1985 Glaciological and climatic controls on lake sedimentation, Canadian Rocky Mountains. Zeitschrift für Gletscherkunde und Glazialgeologie 21: 35-42.

Lidén, R. 1913 Geokronologiska Studier öfver det Finiglaciala Skedet i Ångermanland. Sveriges Geologiska Undersökning 9: 1-39.

1938 Den senkvartära strandförskjutningens förlopp och kronologi i Ångermanland. Geoloziska Föreningens $i$ Stockholm Förhandlingar 60: 397-404.

Lotter, A. F., Ammann, B., Beer, J., Hajdas, I. and Sturm, M. 1992 A step towards an absolute time-scale for the Late-Glacial: Annually laminated sediments from Soppensee (Switzerland). In Bard, E. and Broecker, W. S., eds., The Last Deglaciation: Absolute and Radiocarbon Chronologies. NATO ASI Series I, Vol. 2. Berlin, Springer-Verlag: 45-68.

Lundqvist, J. 1975 Ice recession in central Sweden, and the Swedish Time Scale. Boreas 4: 47-54.

1985 The 1984 symposium on clay-varve chronology in Stockholm. Boreas 14: 97-99.

Olsson, I. 1986 Radiometric dating. In Berglund, B. E., ed., Handbook of Holocene Palaeoecology and Palaeohydrology. New York, John Wiley \& Sons: 273-312.

Perkins, J. A. and Sims, J. D. 1983 Correlation of Alaskan varve thickness with climatic parameters, and use in palaeoclimatic reconstruction. Quaternary Research 20: 308-321.

Possnert, G. 1990 Radiocarbon dating by the accelerator technique. Norwegian Archaeological Review 23(12): 30-37.

Ralska-Jasiewiczowa, M., van Geel, B., Goslar, T. and Kuc, T. 1992 The record of the late Glacial/Holocene transition in the varved sediments of lake Gosciaz, central Poland. Sveriges Geologiska Undersökning Ser. Ca. 81: 257-268.

Renberg, I. 1976 Annually laminated sediments in Lake Rudetjärn, Medelpad province, northern Sweden. $\mathrm{Ge}$ ologiska Föreningens i Stockholm Förhandlingar 98: 335-360.

1981 Formation, structure and visual appearance of iron-rich, varved lake sediments. Verhandlungen des Internationalen Vereins für Limnologie 21: 94-101.

Ringberg, B. 1971 Glacialgeologi och isavsmältning i östra Blekinge. Sveriges Geologiska Undersökning C 661: 1-174.

1991 Late Weichselian clay varve chronology and glaciolacustrine environment during deglaciation in southeastern Sweden. Sveriges Geologiska Undersökning 79: 1-42.

Ringberg, B. and Rudmark, L. 1985 Varve chronology 
based upon glacial sediments in the area between Karlskrona and Kalmar, southeastern Sweden. Boreas 14: 107-110.

Rozanski et al. 1992 The late Glacial-Holocene transition in central Europe derived from isotope studies of laminated sediments from Lake Gosciaz (Poland). In Bard, E. and Broecker, W. S., eds., The Last Deglaciation: Absolute and Radiocarbon Chronologies. NATO ASI Series I, Vol. 2. Berlin, Springer-Verlag: 69-80.

Saarnisto, M. 1986 Annually laminated lake sediments. In Berglund, B. E., ed., Handbook of Holocene Palaeoecology and Palaeohydrology. New York, John Wiley \& Sons: $343-370$.

Sauramo, M. 1923 Studies on the Quaternary varve sediments in southern Finland. Bulletin de la Commission Geologique de Finlande 60: 1-164.

Simola, H. 1977 Diatom succession in the formation of annually laminated sediment in Lovojärvi, southern Finland, during the past 600 years. Annales Botanicaw Fennici 14: 143-148.

Strömberg, B. 1983 The Swedish varve chronology. In Ehlers, J., ed., Glacial Deposits in North-West Europe. Rotterdam, Balkema: 97-105.

1985 Revision of the late glacial Swedish varve chronology. Boreas 14: 101-105.

1989 Late Weichselian deglaciation and clay varve chronology in east-central Sweden. Sveriges Geologiska Undersökning Ca 73: 1-70.

1994 Younger Dryas deglaciation at Mt. Billingen, and clay varve dating of the Younger Dryas/Preboreal transition. Boreas 23: 177-193.

Stuiver, M. and Reimer, P. J. 1993 Extended ${ }^{14} \mathrm{C}$ data base and revised CALIB $3.0{ }^{14} \mathrm{C}$ age calibration program 1993. In Stuiver, M., Long, A. and Kra, R. S., eds., Calibration 1993. Radiocarbon 35(1): 215-230.

Sturm, M. 1979 Origin and composition of clastic varves. In Schlüchter, C., ed., Moraines and Varves. Rotterdam, Balkema: 281-285.

Svensson, N.- O. 1989 Late Weichselian and early Holocene shore displacement in the central Baltic, based on stratigraphical and morphological records from eastern Småland and Gotland, Sweden. LUNDQUA Thesis 25: $195 \mathrm{p}$.

Vogel, J. S., Southon, J. R., Nelson, D. E. and Brown, T. A. 1984 Performance of catalytically condensed carbon for use in accelerator mass spectrometry. Nuclear Instruments and Methods in Physics Research B5: 289-293.

Wohlfarth, B., Björck, S., Lemdahl, G. and Ising, J. 1994 Ice recession and depositional environment in the Blekinge archipelago of the Baltic Ice Lake. GFF 116: 312.

Wohlfarth, B., Björck, S., Possnert, G. and Brunnberg, L. 1995 A comparison between radiocarbon dated Late Weichselian calendar-year chronologies. Journal of Coastal Research Special Issue 17: Holocene Cyclic Pulses and Sedimentation: in press.

Wohlfarth, B., Björck, S., Possnert, G., Lemdahl, G., Brunnberg, L., Ising, J., Olsson, S. and Svensson, N.O. 1993 AMS dating Swedish varved clays of the last glacial/interglacial transition and the potential/difficulties of calibrating Late Weichselian 'absolute' chronologies. Boreas 22: 113-128.

Zbinden, H., Andrée, M., Oeschger, H., Ammann, B., Lotter, A., Bonani, G. and Wölfli, W. 1989 Atmospheric radiocarbon at the end of the last Glacial: An estimate based on AMS radiocarbon dates on terrestrial macrofossils from lake sediments. In Long, A., Kra, R. S. and SrdoX, D., eds., Proceedings of the 13th International ${ }^{14} \mathrm{C}$ Conference. Radiocarbon $31(3)$ : 795-804.

Zeuner, F. E. 1950 Dating the Past. London, Methuen \& Co.: 474 p.

Zolitschka, B., Haverkamp, B., and Negendank, J. F. W. 1992 Younger Dryas oscillation-varve dated microstratigraphic, palynological and palaeomagnetic records from Lake Holzmaar, Germany. In Bard, E. and Broecker, W. S. eds., The Last Deglaciation:Absolute and Radiocarbon Chronologies. NATO ASI Series I, Vol. 2. Berlin, Springer-Verlag: 81-102. 